\title{
A Design of Mine Electrical and Mechanical Equipment of EPON Ring Network
}

\author{
Y. Wu, G.N. Xu \\ Northeast Dianli University \\ Jilin JILIN, 132012, China
}

\begin{abstract}
EPON ring network was applied in networking and cabling of mine to improve mine mechanical and electrical equipment of intelligent system network operation instability as well as high fault rate. When there is a single node failure, there is potentially a paralysis of the entire network system. EPON ring network can improve the safety and reliability of the whole network system.
\end{abstract}

Keywords-EPON; ring network; mechanical and electrical equipment

\section{INTRODUCTION}

Mine mechanical and electrical equipment of intelligent system usually adopts industrial Ethernet in networking and cabling. But the horrible downhole conditions have made sensors of many electrical equipment and detection devices for network information system fail to function well. Thus there are operation instabilities, low accuracy and high failure rate. When there is a single node failure, there is the entire network system paralysis leading to poor reliability. Furthermore, using industrial Ethernet network also has other demerits such as not easy to expansion, higher cost of construction and maintenance. The drawbacks of Network data communication have become bottlenecks of mine mechanical and electrical equipment to update to intelligent.

It's proposed in this paper the EPON ring network was used to the networking, cabling of downhole mechanical and electrical equipment, which can improve the safety and reliability of the whole network system.

\section{EPON SYSTEM ARCHITECTURE}

As a new type of Optical fiber access Network technology, Ethernet Passive Optical Network (EPON) adopts the Passive Optical fiber transmission by Point-to-Multipoint Connection, on Ethernet to offer a variety of business services.

EPON consists of OLT (optical line terminal), the user side equipment ONU (optical network unit) and ODN (light distribution network) and adopts a tree topology. OLT is placed in the center office side, taking charge of allocation and channel connection, as well as real-time monitoring, management and maintenance functions. ONU is placed on the user side, between OLT and ONU by ODN (distribution of passive optical network) connection [1]. EPON system architecture is shown in fig. 1 :

\author{
W.H. Gou, Y.F. Zhang X.D. Wang \\ Jilin Dongjie Science and Technology Development Co., Ltd, \\ Jilin JILIN, 132012, China
}

\section{The AdVANTAgES OF EPON NETWORK APPLIED IN UNDERGROUND}

EPON OLT can support the optical fiber interface, El interface, Ethernet interface, the RS - 232/485 businesses, and the transmission of the WDM. Compared with the traditional Ethernet technology, ONU can realize the up-and-down direction of the data transmission and monitoring. Besides it is easy to maintain the POS equipment without power dissipation. It is easy laid, too. As for long-term use the operating costs and management costs will decrease a lot thus save much fund [2-3].Specific application as shown in Tab. 1:

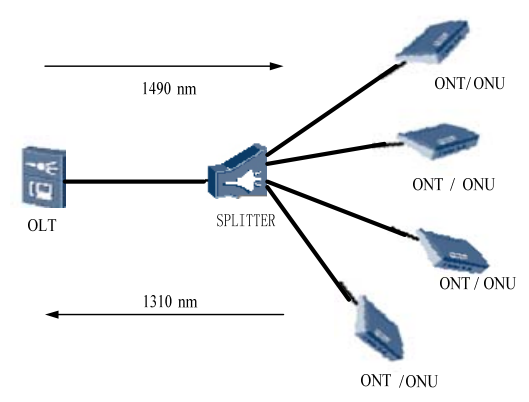

FIGURE I. EPON SYSTEM ARCHITECTURE. 
TABLE I .EPON NETWORK TECHNOLOGY CONTRASTED WITH THE TRADITIONAL ETHERNET TECHNOLOGY.

\begin{tabular}{|c|c|c|}
\hline $\begin{array}{l}\text { Compare } \\
\text { the project }\end{array}$ & $\begin{array}{l}\text { EPON network } \\
\text { technology }\end{array}$ & $\begin{array}{c}\text { Traditional Ethernet } \\
\text { technology }\end{array}$ \\
\hline $\begin{array}{l}\text { Link } \\
\text { protection }\end{array}$ & $\begin{array}{l}\text { Double fiber two-way } \\
\text { technology, main equipment } \\
\text { protection, single fiber } \\
\text { breaking remains protection } \\
\text { ability. }\end{array}$ & $\begin{array}{l}\text { Single fiber breaking, } \\
\text { losing the ability to } \\
\text { protect. }\end{array}$ \\
\hline $\begin{array}{l}\text { Real-time } \\
\text { transmission }\end{array}$ & $\begin{array}{l}\text { Single equipment in loop } \\
\text { way in series, any node data } \\
\text { flow need to flow through to } \\
\text { the next level equipment, } \\
\text { equipment at various levels } \\
\text { will introduce time delay, } \\
\text { but time delay is shorter. }\end{array}$ & $\begin{array}{l}\text { Equipment in loop way } \\
\text { in series, any node data } \\
\text { flow need to flow } \\
\text { through to the next level } \\
\text { equipment, equipment at } \\
\text { various levels will } \\
\text { introduce time delay, } \\
\text { time delay is longer than } \\
\text { the other. }\end{array}$ \\
\hline $\begin{array}{l}\text { Trunk } \\
\text { transmission } \\
\text { rate }\end{array}$ & $\begin{array}{l}\text { All the nodes can be serial } \\
\text { connection, star connection, } \\
\text { flexible network topology. }\end{array}$ & $\begin{array}{l}\text { All nodes must be serial } \\
\text { connection, flexible } \\
\text { network topology. }\end{array}$ \\
\hline $\begin{array}{l}\text { Bandwidth } \\
\text { planning }\end{array}$ & $\begin{array}{l}\text { Unique to the DBA dynamic } \\
\text { bandwidth allocation ability, } \\
\text { flexible configuration, each } \\
\text { node business and } \\
\text { equipment of bandwidth. }\end{array}$ & $\begin{array}{l}\text { Fixed 10M / } 100 \mathrm{M} / \\
1000 \mathrm{M} \text { bandwidth, } \\
\text { when limited bandwidth, } \\
\text { bandwidth allocation } \\
\text { and complex equipment. }\end{array}$ \\
\hline Redundancy & $\begin{array}{l}\text { Support double loop } \\
\text { redundancy switch with host } \\
\text { and optical fiber loop two } \\
\text { redundant functions, even in } \\
\text { the case of double loop all } \\
\text { interrupt will still be able to } \\
\text { star work. }\end{array}$ & $\begin{array}{l}\text { Support single and } \\
\text { double loop, intersecting } \\
\text { rings and other } \\
\text { redundancy switching, } \\
\text { must by the center for } \\
\text { redundancy switching } \\
\text { function. }\end{array}$ \\
\hline $\begin{array}{l}\text { System } \\
\text { reliability }\end{array}$ & $\begin{array}{l}\text { Plug-in data structure, a } \\
\text { single site failure does not } \\
\text { affect the entire ring network } \\
\text { reliability, can realize plug } \\
\text { and play, easy to use. }\end{array}$ & $\begin{array}{l}\text { For active and node } \\
\text { devices, a single node } \\
\text { failure reliability impact } \\
\text { on the entire ring. }\end{array}$ \\
\hline $\begin{array}{l}\text { Channel } \\
\text { security } \\
\text { isolation }\end{array}$ & $\begin{array}{l}\text { Various business data flow } \\
\text { isolation. }\end{array}$ & Unable to isolate. \\
\hline $\begin{array}{l}\text { Expansion } \\
\text { of sexual }\end{array}$ & $\begin{array}{l}\text { Equipment, expansion card } \\
\text { way, plug and play, simple } \\
\text { installation, expansion of } \\
\text { convenient and flexible. }\end{array}$ & $\begin{array}{l}\text { Expansion is more } \\
\text { difficult, need to replace } \\
\text { transmission equipment. }\end{array}$ \\
\hline $\begin{array}{l}\text { Network } \\
\text { maintenance } \\
\text { and } \\
\text { management }\end{array}$ & $\begin{array}{l}\text { Can remote diagnosis, easy } \\
\text { analysis point of failure, } \\
\text { network maintenance and } \\
\text { simple. }\end{array}$ & $\begin{array}{l}\text { Because each subsystem } \\
\text { conversion equipment, } \\
\text { fault point, the overall } \\
\text { network maintenance is } \\
\text { relatively complex. }\end{array}$ \\
\hline
\end{tabular}

EPON network technology has the advantages of single fiber breaking remains protection ability, short transmission delay, flexible networking and support double loop redundancy switching. Furthermore, the construction and maintenance cost is low and the extension and application in mine is of high degree of modularity. This will increase the safety and reliability of network operation.

\section{Mine MEChanicAl ANd ElECtRICAl EQUiPMENT OF THE TRUNK COMMUNICATION RING NETWORK DESIGN}

Ring network structure is based on Epon technology design. It is from the mining of two wellhead line laying down by a wellhead access and by another wellhead derivation. The command center of the platform is to realize a butt joint double vessel network structure. The surface gathering equipment adopts reuse technology ensuring downhole network which produces a breakpoint does not affect the normal operation of the entire network. And underground access devices are not directly involved in ring network, but with the method of the beam splitter which is not used as a network of transport nodes. Therefore, when there is a downhole access device failure, it will not affect the main network, and the maximum ensures the robustness of the network [4-7]. As shown in fig.2 and fig.3 there are mine mechanical and electrical equipment networking principle diagram and ring network structure.

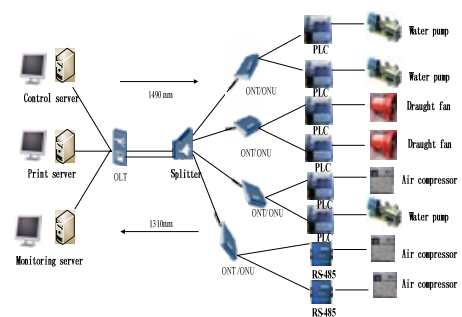

FIGURE II. MINE MECHANICAL AND ELECTRICAL EQUIPMENT NETWORKING DIAGRAM.

\section{SUMMARY}

On the whole, EPON network technology focuses on the current network technology advantages. To some extent, it remains excellent broadband access technology. EPON technology ring network structure will improve underground network system security, reliability and reduce the failure rate. In a word, it is very suitable for poor conditions undermines[8].

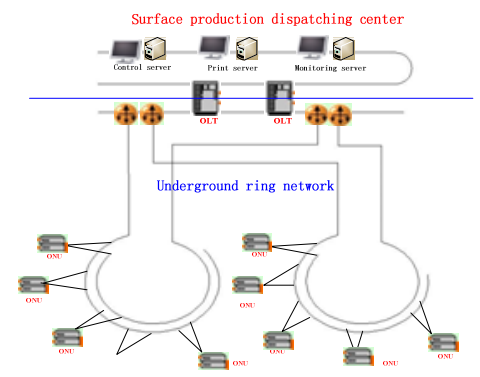

FIGURE III. MECHANICAL AND ELECTRICAL EQUIPMENT IN RING NETWORK.

\section{ACKNOWLEDGEMENT}

This work was supported by the Science and Technology Planning projects of Jilin City (No.201434008), "Twelfth five-year" science and technology research project of jilin province department of education (Mine electrical and mechanical equipment of real-time monitoring and security early warning platform for research.)

\section{REFERENCES}

[1] J. Xu, EPON technology and application, Sci-Tech Information Development \& Economy, 2013, 3(14), pp. 116-118.

[2] L.W. Feng, Y. H. Ma and Y.R. Wang, The application of EPON in power distribution network automation system, Telecommunications for Electric Power System, 2010,31, pp. 24-27. 
[3] Y. Wu, Y.T. Zhou, T. Zuo and X.D. Wang, Based on the design and implementation of RFID electronic seal, Journal of Northeast Dianli University,2013(6), pp. 61-64.

[4] X. Bai, W.Y. Xing, G. Mu, et al., The closed loop current lines for urban medium voltage distribution network analysis, Journal of Northeast Dianli University, 2013,33, pp. 84-88.

[5] G.S. Meng, B.G. Bai and H.B. Yuan, Industrial Ethernet ring network + three layer physical network structure of coal mine automation network platform, Coal mine mechanical and electrical,2014(1) , pp. 124-126.

[6] W.D. An, L. M. Ran, et al., Mine power network based on industrial Ethernet ring network security monitoring system design, Mining Safety Environmental Protection,2007,34(4), pp. 31-34.

[7] H. Ren, Based on the industrial ring network in the application of coal industry, Information Technology, 2012(19), pp. 70-71.

[8] Z.Y. Qu, S.L. Hou et al. ,Realization of Substation Visualization Training Platform, Journal of Northeast Dianli University, 2014, 34(3), pp. 75-79. 